\title{
O AGRONEGÓCIO NO BRASIL: UMA ANÁLISE CONTRA HEGEMÔNICA VOLTADA À SUSTENTABILIDADE E AO DIREITO AO DESENVOLVIMENTO
}

\author{
AGRIBUSINESS IN BRAZIL: A CONTRA HEGEMONIC \\ ANALYSIS DIRECTED TO SUSTAINABILITY AND THE RIGHT TO \\ DEVELOPMENT
}

Patrícia Spagnolo Parise Costa ${ }^{1}$

Estefânia Naiara da Silva Lino²

RESUMO: O agronegócio é instrumento de grande desenvolvimento econômico para o País. As leis brasileiras impôem parâmetros para sua implementaçăo, pautando-o na sustentabilidade. Contudo, será que, de fato, o agronegócio atende aos preceitos legais voltados à sustentabilidade e ao desenvolvimento em todas as suas esferas? Qual o papel do Estado e do Direito neste processo de preservaçăo dos direitos humanos? Diante de tais questionamentos, tem-se com este estudo o objetivo de analisar, a partir de uma visăo contra hegemônica, voltada à sustentabilidade e ao direito ao desenvolvimento, a prática do agronegócio no Brasil. Para tanto, valeu-se da pesquisa bibliográfica, do método de procedimento histórico e do método de abordagem dedutivo. Concluiu-se que o agronegócio nem sempre tem se pautado pela legislaçăo, ou seja, tem ferido leis trabalhistas, causado danos ao meio ambiente, além de aumentar a pobreza e a fome no campo. Para que o agronegócio seja, de fato, bem-sucedido, o governo brasileiro há de pautar suas políticas públicas agrícolas nos critérios da responsabilidade do poder efetivo e na ética da responsabilidade. O Direito possui papel essencial neste processo de reflexăo.

PALAVRAS-CHAVE: Direito ao desenvolvimento. Desenvolvimento sustentável. Direitos humanos. Ética.

ABSTRACT: Agribusiness is an instrument of great economic development for Brazil. Brazilian laws impose parameters for its implementation, guiding it in sustainability. But, in fact, does agribusiness comply with the legal precepts of sustainability and development in all its spheres? What role do the State and Law play in this process

1 Doutoranda em Direito pela UNISINOS/RS; Mestre em Direito pela UNAERP de Ribeirăo Preto/SP; Especialista em Direito Tributário pela PUC/GO; Graduada em Direito pela UniRV; Professora de Direito na Universidade de Rio Verde/GO. parise@unirv.edu.br

2 DoutoraemDireitopelaPUC/SP;MestreemDireitopelaUNITOLEDOdeAraçatuba/SP;GraduadaemDireito pela UEMS; Graduada em Administraçăo pela UFMS; Advogada; Professora da Universidade de Rio Verde. estefanialino@msn.com 
of preserving human rights? From these questions, this study aims to analyze agribusiness practice in Brazil, from a counter-hegemonic vision, concerned with sustainability and the right to development. We used bibliographical research, and the methods of historical procedure and deductive approach. The conclusion was that agribusiness does not always comply with legislation; it has violated labor laws, caused damage to the environment, and increased poverty and hunger in the countryside. In order to make agribusiness, in fact, successful, the Brazilian government has to base its agricultural public policies on the criteria of responsibility of effective power and the ethics of responsibility. Law plays an essential role in this process of reflection.

KEYWORDS: Right to development. Sustainable development. Human rights. Ethics.

\section{INTRODUÇÃO}

O agronegócio no Brasil é um fator essencial para o crescimento econômico. Objeto de estudo do Direito do Agronegócio - o mais novo sub-ramo do Direito Comercial vai além dos limites do campo, unindo as atividades agrícolas, as industriais e as de serviços. É importante para o Brasil e para o mundo todo. Deve, contudo, alinhar-se à ideia de segurança alimentar e de preservaçăo do meio ambiente, com fundamento nos critérios da sustentabilidade e de forma a trazer o desenvolvimento em todas as suas esferas - econômica, social, política, cultural e, também, individual, concretizando, desta forma, os demais direitos fundamentais do homem.

Neste cenário, surge o questionamento se o agronegócio no Brasil se desenrola, de fato, dentro dos parâmetros da sustentabilidade e mais, se ele atua como instrumento de efetivaçăo do direito ao desenvolvimento nas esferas econômica, social, cultural, política e individual, ou se, ao contrário, acaba sendo um agente causador de desigualdades, fundado em um modelo econômico hegemônico, preso às vantagens mercadológicas. Questiona-se, também, qual seria o papel do Estado e do Direito no processo de alinhamento entre as práticas sustentáveis, o direito ao desenvolvimento e as políticas públicas voltadas ao agronegócio.

Com o estudo objetiva-se, portanto, analisar se o agronegócio no Brasil tem se desenvolvido de forma alinhada com a sustentabilidade, tanto no prisma ambiental, quanto social, levando em consideraçăo o fator humano. Pretende-se, ademais, avaliar se as políticas públicas implantadas pelo Estado têm sido efetivas na concretizaçáo de tal desiderato de sustentabilidade e do direito ao desenvolvimento em todas as suas esferas, bem como pontuar possíveis bases teóricas que possam contribuir para uma reflexăo contra hegemônica em termos da atuaçăo do Estado e do papel do Direito neste processo.

Quanto à metodologia utilizada para a conduçăo do estudo, a técnica de pesquisa pauta-se na documentaçăo indireta, por meio da pesquisa bibliográfica.

Em relaçăo ao método de procedimento, o estudo se vale do método histórico, na medida em que o percurso de formaçăo do agronegócio e do Direito do Agronegócio no Brasil săo fundamentais para se atingir os objetivos estipulados. O método de abordagem é o dedutivo. 
O referencial teórico utilizado para buscar respostas ao problema de pesquisa tem respaldo em diversos referenciais teóricos, como Armatya Sen, Hans Jonas, Gladstone Leonel Júnior, Renato Buranello, Elizabete Maniglia, dentre outros. Ressalte-se que o estudo do tema mostra-se essencial no cenário brasileiro atual, na medida em que o agronegócio vem se fortalecendo e, portanto, paralelamente, as políticas públicas e as normas jurídicas dirigidas a ele devem ser pautadas em moldes sustentáveis e com vistas ao direito ao desenvolvimento em todas as suas nuanças.

\section{AGRONÉGÓCIO NO BRASIL}

A importância do agronegócio para a economia brasileira é reconhecida mundialmente. Contudo, sua conceituaçâo é um tanto complexa, uma vez que vai além dos limites do campo, unindo as atividades agrícolas, industriais e de serviços. Também é chamado de rede negocial pelos economistas.

Coelho (2013, p. 16) explica melhor tal conceito:

O agronegócio năo se limita, assim, especificamente à plantaçáo e cultivo das commodities agrícolas (cana, soja, milho, trigo, café etc.), embora esta atividade esteja no centro da rede agronegocial. Também a integram a produçâo e comercializaçăo de sementes, adubos e demais insumos, distribuiçăo, armazenamento, logística, transporte, financiamento, conferência de qualidade e outros serviços, bem como o aproveitamento de resíduos de valor econômico.É, na verdade, a interligaçâo racional de todas essas atividades econômicas que compóem o agronegócio, e năo cada uma delas em separado. [...] 0 agronegócio é a rede em que se encontram o produtor rural (que sabe plantar e colher soja, mas náo compreende e năo quer se expor aos riscos da variaçấo dos preços) e a trading (cuja expertise é o mercado internacional de commodities agrícolas, e os instrumentos financeiros que podem poupar os produtores rurais das oscilaçóes dos preços). Cada um, cuidando daquilo que sabe fazer melhor, contribui para a plena eficiência da integraçăo racional da rede de negócios.

O agronegócio constitui o objeto de estudo de um novo sub-ramo do Direito Comercial, o chamado Direito do Agronegócio, que cuida de institutos jurídicos típicos da relaçâo entre empresários, contudo, năo se confundindo com o Direito Agrário, pois seu objeto repousa sobre os usos da propriedade rural. Importante ainda ressaltar que o Direito do Agronegócio se apoia em princípios próprios, quais sejam: a) funçâo social da cadeia agroindustrial: decorrente do princípio da funçáo social da empresa, estabelece que as atividades econômicas exploradas na cadeia devam contribuir para a proteçáo do meio ambiente e para o aumento da produçáo de alimentos, bioenergia e fibras, com vistas aos desafios globais decorrentes do crescimento populacional, com o intuito de preservar a segurança alimentar; b) proteçâo da cadeia agroindustrial: de acordo com este princípio, a cadeia agroindustrial é um bem juridicamente protegido e isso se deve ao interesse nacional; c) desenvolvimento agroempresarial sustentável: estabelece que todas as atividades inerentes à agricultura, pecuária, exploraçáo florestal e pesca devam ser pautadas no uso adequado da água, do solo, dos recursos genéticos animais e vegetais, também pressupondo os processos técnicos apropriados e economicamente equilibrados; d) integraçâo das atividades em cadeia agroindustrial: segundo o qual o interesse na proteçấo da cadeia se sobrepóe aos interesses individuais dos empresários que a compóem (COELHO, 2013). 
Deve-se ressaltar, a propósito dos princípios que norteiam o Direito do Agronegócio, que aquele definido como integraçăo das atividades em cadeia agroindustrial vai mesmo além dos limites do Brasil, o interesse acaba sendo transnacional. Existem estudos e projeçóes que pontuam que a segurança alimentar do mundo todo depende do desenvolvimento do agronegócio no País. Para o autor, na medida em que a lei assegurar a proteçâo da cadeia sobre interesses individuais dos empresários que a compóem, estará assegurando os direitos de todos os povos e, também, das geraçōes futuras (COELHO, 2013).

É certo que o desenvolvimento está intimamente ligado à modernizaçâo da agricultura. Buranello (2013), traçando um histórico sobre a modernizaçăo da agricultura no Brasil, pontua que esta ocorreu durante a ditadura militar, por meio da retomada de políticas públicas focadas na criaçăo de uma agricultura bastante técnica. Isso com vistas à "expansâo das fronteiras agrícolas, concessâo de créditos e subsídios para o setor, utilizaçăo de novas tecnologias e privilégios aos produtos de exportaçâo ou vinculados a programas energéticos, como o Proálcool" (BURANELLO, 2013, p. 26).

De lá para cá, em virtude dos investimentos em pesquisa e inovaçăo tecnológica, o Brasil vem se tornando um dos principais produtores e exportadores agrícolas do mundo, sendo que o agronegócio contribui para a formaçăo de aproximadamente 30\% do Produto Interno Bruto (BURANELLO, 2013).

Paralelamente, a legislaçâo ambiental brasileira vem criando normas de proteção ao meio ambiente, de forma a garantir que o agronegócio se desenvolva nos parâmetros da sustentabilidade e que possa levar à concretizaçâo da segurança alimentar e ao direito ao desenvolvimento em todas as suas vertentes.

Lembrando que no âmbito do agronegócio também estăo inseridas as práticas do setor de produçâo pecuária, o que requer legislaçôes que imponham mecanismos de inspeçâo industrial e sanitária de produtos de origem animal, de forma a garantir o devido padrâo de qualidade de forma a preservar o direito à alimentaçâo saudável - corolário do direito à saúde e, por consequência, do desenvolvimento do indivíduo e da própria sociedade. Nesta seara encontram-se as leis n. $1.283 / 50$ e 7.889/89, bem como o decreto n $9.013 / 17$.

Mas será que todas estas leis săo respeitadas e o Estado tem implantado políticas que estejam condizentes com a efetivaçăo da preservaçăo do meio ambiente e dos direitos da pessoa? Ou será que, na realidade, as políticas públicas direcionadas ao agronegócio no País têm sucumbido às vantagens mercadológicas, que no final das contas agridem o meio ambiente, geram desigualdades e pior, ao invés de concretizar o direito ao desenvolvimento em todas as suas esferas, acabam tendo por foco somente o enriquecimento dos empresários componentes das redes, em detrimento dos pequenos produtores e da agricultura familiar?

Maniglia (2009) alega que, diante de toda a riqueza angariada no âmbito do agronegócio, persiste a fome e a miséria de milhares de estabelecimentos que nâo produzem, seus condutores vivem em situaçâo de pobreza, nâo sâo alfabetizados e năo há sequer perspectiva de melhora para a situaçăo. A autora explica, também, que os defensores do agronegócio possuem ciência da miséria brasileira 
no campo, mas atribuem responsabilidade exclusiva ao poder público, além de se preocuparem apenas com os seus lucros e com o aumento da produçăo. Acreditam que, desta forma, estáo contribuindo para a erradicaçăo da pobreza.

De fato, a conduçăo do agronegócio é que é o problema, porque o produtor envolvido na rede passa pela concorrência internacional, já que seu produto é de exportaçăo. Muitas vezes, concorre, inclusive, com o produto importado. Na ânsia de năo tomar prejuízo, "efetivam suas práticas agrárias em ofensiva ao meio ambiente, estendem suas áreas, criam conflitos de terras, usam agrotóxicos indiscriminadamente, empregam trabalhadores em condiçóes precárias ou desempregam a populaçâo local" (MANIGLIA, 2009, p. 188).

Leonel Júnior (2016) aponta que as empresas estrangeiras, em especial, assumiram o comércio agrícola e as indústrias brasileiras, controlando preços, estoques e o abastecimento alimentar no País. Contudo, sob um discurso de modernizaçấo da agricultura através das grandes unidades produtivas, têm excluído a agricultura familiar e aos trabalhadores rurais, em geral, tem restado a alternativa de migrar para os centros urbanos. $O$ autor leciona, ainda, que o campo brasileiro tem sido alvo de muitas experiências conturbadas e questionáveis, sob o argumento de se buscar uma maior evoluçăo científica e implantaçăo de tecnologias de ponta, como a produçâo de grăos transgênicos. $O$ autor ainda ressalta que, apesar da necessidade de mais estudos e pesquisas sobre os impactos das sementes transgênicas na saúde humana, o interesse de lucratividade de grandes empresas ligadas à transgenia acaba deixando em segundo plano o direito à segurança alimentar. Ademais, um maior desenvolvimento tecnológico e científico năo representa, necessariamente, melhoria de vida para as pessoas. Os impactos advindos da utilizaçăo de sementes transgênicas mostram-se cada vez mais controversos e potencializadores de danos. A política de desenvolvimento dos transgênicos năo interessa àqueles que lutam por uma agricultura justa, de qualidade e condizente com os direitos humanos.

Pois bem, surge a necessidade de uma reflexăo que venha a quebrar esse paradigma hegemônico em que se encontra a prática do agronegócio no Brasil.

O Estado precisa realizar uma real fiscalizaçăo do cumprimento das leis ambientais e trabalhistas que permeiam as redes e, de fato, punir as empresas que violam o meio ambiente e adotam o trabalho análogo ao escravo, impedindo que tomem empréstimo de dinheiro público, a exemplo do que preconiza a Resoluçăo n. 3545 do Conselho Monetário Nacional/BACEN, que exige documentaçăo comprobatória de regularidade ambiental e outras condicionantes para fins de financiamento agropecuário na regiâo da Amazônia (BACEN, 2008).

Além disso, políticas públicas voltadas à agricultura familiar precisam ser implantadas de forma a se evitar a fome e a miséria no campo. Tudo de acordo com as leis ambientais. Somente desta forma, o agronegócio estará apto a, de fato, propiciar o desenvolvimento em todas as suas dimensôes, dentro dos parâmetros da sustentabilidade.

Nesta seara, abre-se um parêntese para pontuar que o próprio poder público, em diversas situaçôes, acaba sendo condescendente com os produtores da 
rede em práticas lesivas aos direitos humanos e ao meio ambiente, a exemplo da reportagem publicada em 23/07/2017 pelo jornal O Globo, informando sobre a troca de favores entre o Presidente Temer e bancada ruralista da Câmara dos Deputados para conquistar apoio na votaçăo que decidiria se a acusaçáo de corrupçâo contra ele iria para o Supremo Tribunal Federal ou năo. No centro das negociaçōes, figuraria a agenda ambiental, incluindo medidas de flexibilizaçâo de regras de licenciamento ambiental, liberaçăo de agrotóxicos, venda de terras para estrangeiros, além da preparaçáo de uma medida provisória com intuito de anistiar multas, conceder descontos e prazos maiores para pagamento das dívidas bilionárias de produtores ao Fundo de Assistência ao Trabalhador Rural - Funrural (O GLOBO, 2017).

Outro exemplo ligado à omissáo do Estado na esfera do agronegócio é o da notícia divulgada em 17/12/2016, pelo Boletim de Notícias Consultor Jurídico, em que a Corte Interamericana de Direitos Humanos da Organizaçăo dos Estados Americanos (OEA) responsabilizou o Brasil internacionalmente por năo prevenir a prática de trabalho escravo moderno no caso Trabalhadores da Fazenda Brasil Verde vs. Brasil (CONJUR, 2016, n.p.). A nota do Boletim ainda informou que:

O Estado brasileiro tem um ano para indenizar cada uma das 128 vítimas resgatadas durante fiscalizaçôes do Ministério Público do Trabalho na Fazenda Brasil Verde, no sul do Pará, nos anos de 1997 e 2000. Somente nessa fazenda, mais de 300 trabalhadores foram resgatados, entre 1989 e 2002. Em 1988, houve uma denúncia da prática de trabalho escravo na Fazenda Brasil Verde, no Pará, e o desaparecimento de dois adolescentes que teriam tentado fugir.

Ainda segundo a Corte, o Poder Judiciário é cúmplice da discriminaçăo desses trabalhadores escravizados. As reparaçōes vấo custar aos cofres públicos cerca de US\$ 5 milhōes [...] (CONJUR, 2016, n.p.).

A propósito do trabalho escravo, há de se mencionar a reportagem da Revista Veja acerca da lista suja de trabalho escravo, publicada em 24/03/2017. A referida lista, que nâo era divulgada desde 2014, voltou a ser publicada pelo governo federal depois de uma longa batalha judicial e de uma denúncia contra o Brasil na sessăo do Conselho de Direitos Humanos da ONU, na Suíça (VEJA, 2017, n.p.).

Diante destes exemplos, observa-se que o Estado precisa repensar seu papel na seara das políticas públicas voltadas ao agronegócio.

E para que se prossiga a tal discussâo, necessário se faz analisar os elementos que se entrelaçam com o agronegócio e que devem orientar suas práticas.

\section{AGRONEGÓCIO, DESENVOLVIMENTO E DIREITO AO DESENVOLVIMENTO}

Năo há como olvidar que o agronegócio tem desempenhado importante papel para o desenvolvimento econômico brasileiro. Contudo, o termo desenvolvimento vai além do aspecto econômico, tal conceito envolve um conteúdo bem mais amplo do que possa parecer.

Desenvolvimento, segundo Sen (2010), se coaduna com a expansâo das liberdades substantivas. Para o autor, o desenvolvimento denota um processo de expansâo das liberdades que os sujeitos desfrutam. A expansâo das liberdades humanas é vista, de 
maneira concomitante, como o fim primordial (ou papel constitutivo) e como o principal meio do desenvolvimento (ou papel instrumental).

A funçăo constitutiva, para Sen (2010), diz respeito à importância da chamada liberdade substantiva para o engrandecimento da vida. As liberdades substantivas incluem diversas capacidades, como a de evitar privaçóes como a fome e mortalidade prematura, ou educaçăo, saúde, alimentaçăo equilibrada etc.

Paralelamente, a eficácia da liberdade em seu papel instrumental apresenta-se na inter-relaçăo entre diferentes tipos de liberdade, o que significa que um tipo de liberdade pode contribuir para liberdades de outros tipos: liberdades políticas (incluem os direitos políticos associados à democracia); facilidades econômicas (oportunidades que as pessoas têm para utilizar recursos econômicos com propósitos de consumo, produçăo ou troca); oportunidades sociais (disposiçôes estabelecidas pela sociedade, por exemplo, nas áreas da saúde e educaçăo, que influenciam a liberdade de o indivíduo ter uma vida melhor); garantias de transparência (como inibidoras da corrupçâo, da ilicitude e da irresponsabilidade financeira); segurança protetora (com o intuito de viabilizar uma rede de segurança social, impedindo que os vulneráveis sejam reduzidos à miséria abjeta, à fome e à morte). Em suma, o desenvolvimento é o processo de expansăo das liberdades humanas, que se dá pelo alinhamento da funçăo constitutiva e a instrumental da liberdade (SEN, 2010).

Aprofundando-se um pouco mais na teoria de Armatya Sen, vale pontuar que esta se encontra fundada na ideia de desenvolvimento como liberdade, a partir do que ele chama de capacidades e funcionamentos (capability approach). Os funcionamentos (cujo conceito possui suas raízes na obra de Aristóteles) designam as diversas coisas que os indivíduos podem considerar como valioso ter ou fazer (ser nutrido, livre de doenças evitáveis, atividades, respeito próprio etc.). As capacidades, por sua vez, sâo as liberdades substantivas de realizar combinaçôes de funcionamentos, ou seja, liberdades para ter estilos de vida diferentes (SEN, 2010).

O enfoque avaliatório dessa "abordagem da capacidade" pode ser sobre os funcionamentos realizados (o que uma pessoa realmente faz) ou sobre o conjunto capacitário de alternativas que ela tem (suas oportunidades reais). Em cada caso há tipos diferentes de informaçóes - no primeiro, sobre as coisas que uma pessoa faz, e, no segundo, sobre as coisas que a pessoa é substancialmente livre para fazer (SEN, 2010, p. 105-106).

Importante colocar outros aspectos da teoria de Sen (2011) que se alinham com a capability approach e com a proposta do presente estudo, que é a de pontuar formas de se ampliar o agronegócio no Brasil, nos parâmetros de sustentabilidade e de forma condizente com o desenvolvimento social e ao direito ao desenvolvimento.

Entre eles, o conceito de discussâo pública de Sen (2011), com vistas ao ajuste e à correçâo do comportamento no que tange ao que foi acordado com as instituiçóes sociais. Este é um elemento que se entrelaça com a noçăo de imaginaçăo institucional/ experimentalismo democrático de Unger (2004), cuja crença é a de que para se criar futuros alternativos para a sociedade, deve-se ser capaz de imaginá-los e discuti-los, a partir da prática do debate público, numa democracia. Neste contexto, tanto Unger como Sen defendem o papel ativo da sociedade civil no processo, devidamente alinhada à ideia de gestâo local, instrumento de aproximaçăo dos sujeitos sociais às políticas públicas. 
Visualizando alternativas para o fortalecimento da sociedade civil, Unger (2004) propôe a sua organizaçâo com fundamento em vizinhança, trabalho ou preocupaçōes e responsabilidades compartilhadas, bem como a criaçăo de normas e redes de vida em grupo fora do Estado, paralelas ao Estado e inteiramente livres de influência estatal. 0 intuito de tal arranjo é o de fomentar o debate acerca das necessidades das comunidades locais em termos de políticas públicas. É importante propiciar a aproximaçáo entre tais esferas de sociedade civil organizada e os conselhos gestores dos municípios, de forma a forçar uma maior transparência e uma atuaçăo mais dinâmica no setor agrícola e no ambiental. O autor aponta, também, o essencial papel do Direito na construçăo de novos paradigmas, unindo as condiçóes de progresso material e emancipaçáo individual. Imagina a reflexăo jurídica como o fio condutor dessa proposta, desde que desgarrada do que ele chama de fetichismo institucional, ou seja, na crença em concepçōes institucionais abstratas como uma expressăo institucional única, natural e necessária.

É justamente nesta esfera que precisa ser repensado o agronegócio no Brasil. As ideias de Sen e de Unger podem vir a sensibilizar as práticas do agronegócio, na medida em que convergem para a importância do estabelecimento de políticas públicas no setor que possam satisfazer tanto os grandes produtores como a agricultura familiar.

Ainda há de se acrescentar que a ideia de responsabilidade do poder efetivo é aspecto relevante no processo de estabelecimento de políticas públicas nos diversos setores da vida e, no caso em tela, no setor agropecuário. Consiste no argumento de que "se alguém tem o poder de fazer a diferença na reduçăo da injustiça no mundo, entăo há um forte e fundamentado argumento para que faça exatamente isso" (SEN, 2011, p. 305).

Em outras palavras, quando se tem consciência dessa responsabilidade em virtude do poder efetivo, é possível ajudar na promoçâo da liberdade de todos em uma sociedade. Ressalte-se que tal argumento distancia-se da noçăo de benefício mútuo, característico do contratualismo e, sem dúvidas, pode vir a ser um fator de reflexâo com o intuito de sensibilizar as redes de agronegócio no Brasil, de forma a que desenvolvam suas atividades de maneira sustentável, com respeito às normas trabalhistas e de forma a conviver, inclusive, com a agricultura familiar. Desta forma, o direito ao desenvolvimento poderá se tornar efetivo.

A propósito do direito ao desenvolvimento, Peixinho e Ferraro (2015) explicam que se trata de um direito de terceira dimensấo, uma categoria de direito de solidariedade, que foi firmado na década de 1960 e positivado na Declaraçâo sobre o Direito ao Desenvolvimento das Naçôes Unidas de 1986, sendo confirmado na Conferência de Viena sobre Direitos Humanos de 1993. Trata-se de um direito fundamental inalienável, que, inclusive, constitui um dos objetivos fundamentais da República Federativa do Brasil, estabelecido no artigo $3^{\circ}$ da Constituiçăo Federal.

O direito ao desenvolvimento cabe a todos os brasileiros, indistintamente. Sejam grandes ou médios e pequenos produtores, sejam empresários das redes do agronegócio ou camponeses da agricultura familiar. 


\section{A IDEIA DE SUSTENTABILIDADE}

Muito se fala sobre sustentabilidade. Que o agronegócio precisa fundar-se em práticas sustentáveis. Tais colocaçôes acabam sendo direcionadas, na maioria das vezes, para a sustentabilidade ambiental. Entretanto, a palavra sustentabilidade năo pode ser entendida somente sob o ponto de vista ecológico já que, de fato, possui vertentes múltiplas às quais o Estado deve atentar-se enquanto detentor do papel de proteçấo dos direitos fundamentais, dentre eles: o meio ambiente ecologicamente equilibrado, a alimentaçăo saudável e o direito ao desenvolvimento.

Neste contexto, Sachs (2002, p. 85-87) ensina as diversas concepçóes de sustentabilidade que o Estado deve observar para orientar suas açóes:

Sustentabilidade social, por meio da distribuiçáo de uma renda justa, patamar de homogeneidade social razoável, emprego pleno e/ou autônomo com vida decente, igualdade no acesso aos recursos e serviços sociais.

A sustentabilidade cultural com capacidade de autonomia para elaboraçăo de um projeto nacional integrado e endógeno (em oposiçăo a cópias servis dos modelos alienígenas), mudança no interior da continuidade (equilíbrio entre respeito à tradiçâo e inovaçáo), autoconfiança combinada com a abertura para o mundo.

Sustentabilidade ambiental, respeitar e realçar a capacidade de autodepuraçáo dos ecossistemas naturais.

Sustentabilidade econômica, desenvolvimento econômico intersetorial equilibrado, segurança alimentar, capacidade de modernizaçăo contínua. Dos instrumentos de produçấo, razoável nível de pesquisa científica e tecnológica e inserçăo soberana na economia internacional.

Sustentabilidade política, democracia definida em termos de apropriaçáo universal dos Direitos Humanos, desenvolvimento da capacidade do Estado de implementar o projeto nacional em parceria com todos os empreendedores, um nível razoável de coesâo social.

Sustentabilidade da política internacional, eficácia do sistema de prevençăo de guerra da $\mathrm{ONU}$, na garantia da paz e na promoçăo da cooperaçâo internacional. Pacote de desenvolvimento firmado em regras baseadas em igualdade. Controle institucional efetivo do sistema internacional financeiro e de negócios, controle institucional efetivo da aplicaçăo do princípio da precauçăo do meio ambiente.

Note-se, assim, que para que o Estado atue efetivamente na proteçáo dos direitos fundamentais estará "adstrito a uma série de normatizaçóes, fatores internacionais, variáveis múltiplas nas relaçôes entre pobres e ricos, concepçôes do progresso, pressôes das grandes empresas, o que dificulta e obstrui, muitas vezes, os objetivos daquilo a que se propóe como meta" (MANIGLIA, 2009, p. 122).

Em tal seara, emerge como fator essencial para a superaçáo de tais dificuldades resultantes das variáveis múltiplas a participaçâo da sociedade civil e a responsabilidade do poder efetivo, enquanto instrumentos de ruptura de posturas hegemônicas nas práticas do agronegócio. 
O agronegócio, sendo processado a partir da reflexăo sobre os mecanismos de produçăo, em que a economia caminhe junto com a ecologia e a sustentabilidade social, pode e deve ser executado. Há de se ressaltar que diversas empresas agrícolas têm atuado na produçấo limpa, sustentável, a exemplo das empresas agrícolas de café de Cornélio Procópio e de açúcar de Sertăozinho. Dessa forma, ganham dinheiro, selos internacionais, incentivos que se convertem em benefícios para as próprias empresas. Por outro lado, existem outras, em Santa Catarina, que atuam voltadas para o comércio exterior, sem sustentabilidade alguma, contaminando o solo e as águas com dejetos suínos (MANIGLIA, 2009).

Desta forma, ainda no entender de Maniglia (2009, p. 189), “o agronegócio é vilāo quando seu modelo é de destruição ambiental e humana. Com políticas públicas atuantes, pode-se convertê-lo em outro papel, desde que năo concentre terras, nem gere desigualdades".

É preciso educar o povo para demonstrar que a terra năo é reserva de valor, năo deve ser explorada, mas utilizada de forma sustentável. Deve ser ela o meio de sobrevivência das geraçóes, merecendo tratamento diferenciado. A agricultura é o meio de alimentaçâo universal de interesse público, portanto, suas normas devem atender aos clamores sociais e náo ao interesse de grupos (MANIGLIA, 2009, p. 190).

Portanto, é necessário refletir sobre a criação de políticas públicas que contemplem mudanças e incentivos ao meio rural, que possam criar oportunidades a todos os atores do campo. É possível que todos os envolvidos no processo possam se beneficiar com uma política agrícola garantidora de direitos a toda a população rural.

\section{4 ÉTICA E AGRONEGÓCIO}

A humanidade tem à sua disposiçăo, nos dias de hoje, um arsenal tecnológico até entâo inimaginável. A açâo humana tem propiciado tantas inovaçóes, inclusive no campo, em atendimento ao agronegócio, que acabou criando um cenário em que novos dilemas éticos surgem a cada dia. As novas tecnologias no campo, além de elitizadas, levantam questionamentos até mesmo em relaçâo à própria saúde humana e do bioma.

O fato é que os conceitos éticos tradicionais já nâo respondem mais a estes desafios. De acordo com Jonas (2006), nem mesmo a ética fundada no amor ao próximo, nutrida dos sentimentos de justiça, misericórdia, honradez, têm se mostrado efetiva para operar nesse novo contexto.

Trata-se da sobreposiçấo do homo faber sobre o homo sapiens: "o triunfo do homo faber sobre o seu objeto externo significou, ao mesmo tempo, o seu triunfo na constituiçấo interna de homo sapiens, da qual outrora ele costumava ser uma parte servil" (JONAS, 2006, p. 43).

E para ilustrar tal observaçăo, Fonseca (2009) pontua alguns aspectos da obra de Hans Jonas que se entrelaçam com as novas tecnologias: a própria alimentaçâo, tema suscitado em virtude do aumento demográfico, o que vai exigir maior exploraçăo dos solos, recursos mais intensos e adubos artificiais, provocando a contaminaçâo química dos mananciais; por outras causas, a salinizaçăo do solo, erosăo, as chuvas ácidas e 
outros; o das matérias- primas que, ao nível em que săo exploradas, năo săo inesgotáveis.

Jonas (2006) propóe, entăo, uma filosofia da tecnologia, ou seja, a criaçáo de uma ética do futuro, fundada em uma nova orientaçáo política. Assim, elege a responsabilidade como princípio fulcral para orientar a açăo humana e fundamentar uma ética para a era tecnológica.

Barreto (2013, p. 326) explica sobre a ética da responsabilidade em Hans Jonas:

\begin{abstract}
A inovaçăo de uma ética da responsabilidade dirigida ao futuro consiste na obrigaçáo de náo deixarmos que o futuro longínquo cuide de si mesmo. A responsabilidade possui um caráter total, em que há uma relaçáo de cuidado contínua. O exercício da responsabilidade náo pode ser interrompido. Hans Jonas compara a responsabilidade orientada para o futuro com a responsabilidade dos pais ou do governo. $\mathrm{O}$ cuidado dos pais ou do governo náo pode tirar férias. [...] a responsabilidade orientada para o futuro exige do governante políticas públicas que preservem as condiçóes de existência daqueles que estăo por vir. Para tanto, deverăo ser realizadas projeçóes do futuro para a tomada de decisóes no presente.
\end{abstract}

Veja-se, entâo, que nesta perspectiva ética, o homem assume a responsabilidade de cuidar daquele que está por vir, ou seja, toma para si a obrigaçăo moral de preservar a liberdade das próximas geraçóes. E é exatamente este o papel que o Estado brasileiro deve abraçar ao traçar políticas públicas para o setor agrícola, de forma a propiciar, paralelamente a um agronegócio realmente sustentável, mecanismos voltados também aos pequenos agricultores, de forma a minimizar a pobreza no campo e a fome. Desta forma, todos podem usufruir o direito ao desenvolvimento em todas as suas esferas.

\title{
50 PAPEL DO ESTADO E DO DIREITO NO PROCESSO DE ALINHAMENTO ENTRE AS PRÁTICAS SUSTENTÁVEIS, O DIREITO AO DESENVOLVIMENTO E AS POLÍTICAS PÚBLICAS NO SETOR DO AGRONEGÓCIO
}

O Direito é elemento fulcral para propiciar o alinhamento entre sustentabilidade, direito ao desenvolvimento e a definiçâo das políticas públicas direcionadas às práticas do agronegócio, de forma que este venha a se desenvolver em um patamar de respeito aos direitos fundamentais.

O papel do Direito deve ser repensado a partir de uma perspectiva contra hegemônica, diferente dos atuais moldes em que atua - como instrumento de opressáo. A realidade brasileira, já tăo desgastada pela miséria e pela desigualdade, já náo tem mais como se submeter a um Direito hegemônico, distante da realidade social de seu povo.

Leonel Júnior (2016) acredita que o Direito deve ser usado em defesa dos povos e que o enfrentamento à política agrária dirigida ao agronegócio é tarefa do jurista comprometido com seu povo, de forma a conceber um projeto social que leve em conta o potencial humano e nấo as vontades do mercado.

Nesta mesma linha de pensamento, Maniglia (2009, p. 117) alerta que é preciso lembrar que "as novas concepçōes sobre o papel do Estado e das normas jurídicas no mundo contemporâneo sâo fundamentais para a realizaçăo do bem comum". 
Vale acrescentar que:

O direito como agente de justiça social deve ser o grande impulsionador da formaçăo da cidadania. A cidadania passa pelo ser pessoa - ninguém pode ser cidadăo sem ser pessoa. O político e o jurídico têm um pré-requisito existencial. A cidadania acresce o ser pessoa, projeta no político, no comunitário, no social e no jurídico a condiçấo de ser pessoa. Nâo há como florescer a cidadania se náo se realizam as condiçôes de humanismo existencial (HERKENHOFF, 2001, p. 88).

Herkenhoff (2001, p. 89) prossegue em suas pontuaçōes, afirmando que no mundo muitos náo podem ser pessoas, ao contrário, săo párias na escala social, na medida em que:

[...] estăo à margem de qualquer direito, à margem do alimento que a terra produz, à margem do trabalho e do emprego, à margem do mercado, à margem da participaçáo política, à margem da cultura, à margem da fraternidade, à margem do passado, do presente e do futuro, à margem da história, à margem da esperança. Essa é a face negativa da cidadania, criada por modelo socioeconômico de cunho internacional que revela a fome e a miséria dos povos.

Reforçando a necessidade de se repensar o papel do Direito neste contexto, Santos (2002) pontua que cabe ao Direito o papel de gestăo reconstrutiva dos excessos e dos défices advindos da modernidade ocidental. Trata-se da crise paradigmática inerente ao Direito, que se coloca entre regulaçăo e emancipaçáo.

O Estado brasileiro, portanto, precisa revestir-se de responsabilidade para com a parcela da populaçăo pária, fazendo uso do Direito em uma perspectiva contra hegemônica, de forma a atender, de fato, às necessidades sociais. No cenário do agronegócio, tal postura é essencial. A riqueza é deveras importante para um povo, mas năo deve sobrepujar a pessoa. Sucumbir aos benefícios puramente mercadológicos é desconsiderar o ser humano como o fim maior de toda a atuaçăo do Estado.

\section{CONSIDERAÇÕES FINAIS}

O agronegócio é, inegavelmente, fator de essencial importância para o crescimento econômico do País. Desde que implantado e desenvolvido de forma sustentável e voltado à preservaçăo dos direitos humanos, há de ser valorizado na proporçâo de sua expressividade para o desenvolvimento.

Contudo, náo é razoável imaginar o desenvolvimento somente no cenário econômico, com o enriquecimento de poucos e o empobrecimento de muitos. Há de se propor açóes sérias no sentido de se entrelaçar as práticas do agronegócio com o real sentido do desenvolvimento nas esferas social, política, cultural e mesmo individual, e do próprio direito ao desenvolvimento na condiçâo de inalienabilidade. Somente desta forma há de se falar em desenvolvimento e sustentabilidade em suas acepçóes mais amplas.

O governo brasileiro tem deixado aquém tais preceitos ao apoiar as políticas públicas no setor agrícola em atendimento a permutas de cunho político, valorizando mais os aspectos econômicos do que os humanos. Dessa forma, tem permitido lesôes ao meio ambiente por meio de leis permissivas e nâo tem investido 
na concretizaçấo dos direitos das pessoas do campo, que vivem em contexto de extrema pobreza.

Neste cenário, emerge a importância dos conceitos de responsabilidade do poder efetivo de Armatya Sen e da ética da responsabilidade proposto por Hans Jonas. Sobre a primeira acepçâo, há de se pensar na responsabilidade que cada ser humano tem como detentor da oportunidade de implantar as açôes que possam trazer melhoras para os outros. E na perspectiva de Jonas, é preciso planejar as açóes do presente com vistas às possíveis consequências futuras, de forma a preservar os direitos das próximas geraçōes.

Assim, deve atuar o Estado brasileiro na criaçăo de políticas públicas no setor agrícola de forma ética e responsável, com vistas a propiciar o desenvolvimento sustentável em todas as suas esferas e de forma que tanto os grandes produtores da rede como os pequenos produtores e os camponeses possam ter acesso a uma vida digna no que concerne a trabalho, alimentaçăo, saúde e ambiente ecologicamente equilibrado. O fator econômico năo pode preponderar sobre o humano.

O papel do Direito nesse processo é imprescindível. É preciso haver uma reflexăo no âmbito da Ciência Jurídica e compreender que açăo do jurista vai além do uso que lhe direciona o Estado. Há de se romper com a atuaçăo hegemônica em termos de políticas públicas voltadas ao desenvolvimento. Isso cabe tanto ao Estado como ao Direito. Somente assim pode-se pensar, de fato, em justiça social no âmbito econômico e, em específico, das práticas do agronegócio. 


\section{REFERÊNCIAS}

BARRETTO, Vicente de Paulo. O fetiche dos direitos humanos e outros temas. Porto Alegre: Livraria do Advogado, 2013.

BRASIL. Presidência da República. Lei n. 1.283, de 18 de dezembro de 1950. Dispóe sobre a inspeçấo industrial e sanitária dos produtos de origem animal. Disponível em: 〈http://www.planalto.gov.br/ccivil 03/leis/L1283.htm〉. Acesso em: 20 jul 2017.

BRASIL. Presidência da República. Lei n. 7.889, de 23 de novembro de 1989. Dispóe sobre inspeçâo sanitária e industrial dos produtos de origem animal, e dá outras providências. Disponível em: < http://www.planalto.gov.br/ccivil 03/leis/L7889. $\underline{\text { htm }}$. Acesso em: 20 jul 2017.

BRASIL. Presidência da República. Decreto n. 9.013, de 29 de março de 2017. Regulamenta a Lei ${ }^{0} 1.283$, de 18 de dezembro de 1950, e a Lei $n^{0} 7.889$, de 23 de novembro de 1989, que dispóem sobre a inspeçâo industrial e sanitária de produtos de origem animal. Disponível em: < http://www.planalto.gov.br/ccivil 03/_ato20152018/2017/decreto/D9013.htm>. Acesso em 20 jul 2017.

BURANELLO, R. Manual do direito do agronegócio. Sāo Paulo: Saraiva, 2013.

COELHO, F. U. Prefácio. In: Manual do direito do agronegócio. Sâo Paulo: Saraiva, 2013.

CONSELHO MONETÁRIO NACIONAL. Resoluçâo n. 3545 de 29 de fevereiro de 2008. Altera o MCR 2-1 para estabelecer exigência de documentaçăo comprobatória de regularidade ambiental e outras condicionantes, para fins de financiamento agropecuário no Bioma Amazônia. Disponível em: <http://www.bcb.gov.br/pre/normativos/res/2008/ pdf/res_3545_v1_o.pdf>. Acesso em 27 fev 2017.

CONJUR. Em decisăo inédita, Corte Interamericana condena Brasil por trabalho escravo. Disponível em: <http://www.conjur.com.br/2016-dez-17/brasil-condenado-corte-interamericana-trabalho-escravo>.Acesso em 17/12/2016.

FONSECA, Flaviano Oliveira. Hans Jonas: ética para a civilizaçāo tecnológica. Cadernos de Ciências Sociais Aplicadas, n. 5/6. Vitória da Conquista-BA, 2009, p. 151-168.

HERKENHOFF, J. B. Para onde vai o direito? Porto Alegre: Livraria do Advogado, 2001.

JONAS, H. O princípio responsabilidade: ensaio de uma ética para a civilizaçăo tecnológica. Traduçâo de Marijane Lisboa e Luiz Barros Montez. Rio de Janeiro: Contraponto; Editora PUC-Rio, 2006. 
LEONEL JÚNIOR, G. Direito à agroecologia: a viabilidade e os entraves de uma prática agrícola sustentável. 1. ed. Curitiba: Editora Prismas, 2016.

MANIGLIA, E. As interfaces do direito agrário e dos direitos humanos e a segurança alimentar. Săo Paulo: Cultura Acadêmica, 2009.

O GLOBO. De olho em 211 votos do agronegócio, Temer ameaça política ambiental: bancada ruralista representa 41\% dos parlamentares da Câmara. Disponível em: 〈https:// oglobo.globo.com/brasil/de-olho-em-211-votos-do-agronegocio-temer-ameaca-politica-ambiental-21621738>. Acesso em 23 jul 2017.

PEIXINHO, M.M.; FERRARO, S.A. Direito ao desenvolvimento como direito fundamental. XXIV Congresso do CONPEDI. Belo Horizonte, 2015. Disponível em: <http://www.publicadireito.com.br/conpedi/manaus/arquivos/anais/bh/manoel_messias_peixinho.pdf.>. Acesso em: 27 fev 2017.

VEJA. Após denúncia, governo publica 'lista suja' de trabalho escravo: publicaçăo da lista estava suspensa desde 2014 por decisăo judicial. <http://veja.abril.com.br/economia/apos-denuncia-governo-publica-lista-suja-de-trabalho-escravo/ >. Acesso em: 01 jul 2017.

SACHS, I. Caminhos para o desenvolvimento sustentável. Org. Paula Ione Stroh. Rio de Janeiro: Garamond, 2002.

SANTOS, Boaventura de Sousa. A crítica da razāo indolente: contra o desperdício da experiência para um novo senso comum. A ciência, o direito e a política na transiçāo paradigmática. 4. ed. São Paulo: Cortez, 2002.

SEN, A. Desenvolvimento como liberdade. Trad. Laura Teixeira Motta. Săo Paulo: Companhia das Letras, 2010.

SEN, A. A ideia de justiça. Trad. Denise Bottmann, Ricardo Doninelli Mendes. Săo Paulo: Companhia das Letras, 2011.

UNGER, Roberto Mangabeira. O direito e o futuro da democracia. Trad. Caio Farah Rodrigues, Marcio Soares Grandchamp. Săo Paulo: Boitempo, 2004. 